\title{
Catch variability and growth of pink shrimp (Farfantepenaeus paulensis) in two coastal lagoons of uruguay and their relationship with ENSO events
}

\author{
Orlando Santana, Santiago Silveira, Graciela Fabiano
}

\author{
Dirección Nacional de Recursos Acuáticos (DINARA) - Unidad de Gestión Pesquera Atlántica (UGEPA). Uruguay \\ (Av. Portuaria s/n. Puerto de La Paloma-Rocha-Uruguay. CP 27001) \\ *Corresponding author: osantana@dinara.gub.uy
}

\begin{abstract}
The pink shrimp Farfantepenaeus paulensis (Pérez Farfante, 1967) is distributed along the Atlantic Coast from Bahia (Brazil) to Mar del Plata (Argentina). The larval stages enter the Uruguayan brackish water lagoons during late spring to summer associated with tidal currents of the Brazilian Current. In such environments the growth is accelerated and in early autumn the individuals attain commercial size, supporting important regional artisanal fisheries. The pink shrimp catches from 1988 to 2013 were analyzed and related to phenomena of climate variability in ENSO events and to the growth of the species. The total catch ranges from 0.7 to 162 tons. The variation in catches has a negative relationship with the varied climatic events caused by El Niño. Growth parameters yielding values of $\mathrm{L} \infty=177$ $\mathrm{mm}$ (total carapace length) and $\mathrm{K}=1.48$ for the period 2009-2013. These values differ slightly from those calculated for natural populations in southern Brazil, suggesting that the population is the same and thus implying the need for coordinated fisheries management between the two countries.
\end{abstract}

Descriptors: Coastal lagoons, Pink shrimp, Climatic variability, Growth parameters.

\section{Resumo}

O camarão rosa Farfantepenaeus paulensis (Pérez Farfante, 1967) distribui-se ao longo da costa atlântica do Brasil (Bahia) até a Argentina (Mar del Plata). Os estágios larvais entram na primavera-verão nas lagoas salobras do Uruguai associados com correntes de maré, onde a água dominante é da Corrente do Brasil. Nesses ambientes, o crescimento é acelerado e no início do outono geralmente atinge o tamanho comercial, apoiando importantes pescarias regionais. A captura de camarão foi analisada nas lagoas costeiras uruguaias entre 1988 e 2013 e relacionadas com os fenômenos da variabilidade climática em eventos ENSO e com elementos da dinâmica populacional da espécie. A captura total variou entre 0,7 e 162 ton. A variação das capturas apresentou relação negativa com os eventos de variabilidade climática causados pelo El Niño. Os parâmetros de crescimento analisados originaram valores de $\mathrm{L} \infty=177 \mathrm{~mm}$ (comprimento total) e $\mathrm{K}$ $=1,48$ no período 2009 -2013. Esses valores são ligeiramente diferentes dos calculados para populações naturais no sul do Brasil, o que sugeriria a existência de uma mesma população, implicando na necessidade de coordenação pesqueira entre os dois países.

Descritores: Lagoas costeiras, Camarão rosa, Variabilidade climática, Parâmetros de crescimento. 


\section{INTRODUCTION}

Farfantepenaeus paulensis (PÉREZ FARFANTE, 1967 ) is a subtropical decapod species with a distribution range from Ilheus (Brazil) to Mar del Plata (Argentina). Its life cycle has two distinct phases, one oceanic, marked by the reproduction and development of larvae (nauplius, protozoea and mysis) and the other estuarine, characterized by the growth of juveniles until the period of migration back to the ocean (D'INCAO, 1991; 1999). The parental stock was found in waters of the continental shelf around the São Paulo and Santa Catarina states in Brazil (ZENKER and AGNES, 1977; D'INCAO, 1991; GUSMÃO et al., 2005). Postlarvae are transported passively southward by the Brazilian Current and enter the coastal lagoons of Uruguay in late spring - early summer (VILLEGAS, 1974; SANTANA and FABIANO, 1992) (Fig. 1). Once in these ecosystems, juveniles grow fast during the warm season (December to April). When temperatures and salinity begin to decrease in autumn, the individuals start their migration to the reproduction grounds and leave the lagoons (D'INCAO, 1991; SANTANA and FABIANO, 1999); at this moment the fishery begins its activity throughout the autumn (March to May).

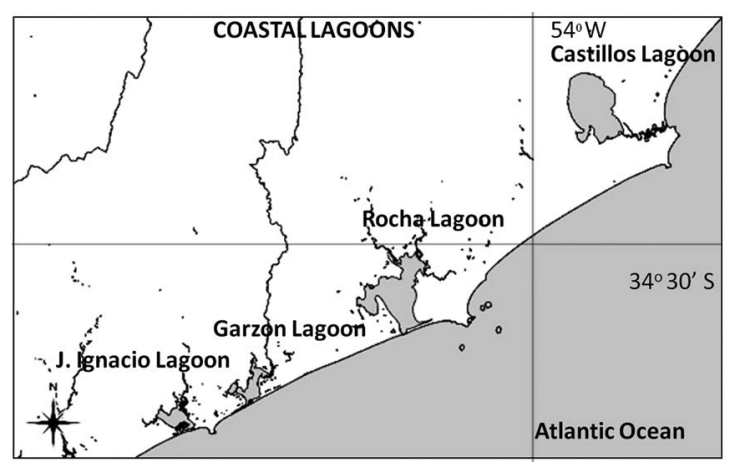

Figure 1. Coastal lagoons of Uruguay (Castillos, Rocha, Garzón and José Ignacio) where shrimp fishing can occur.

Penaeid shrimp species exhibit unique characteristics with respect to population dynamics and fisheries, particularly has the relationship between recruitment and spawning stock in fisheries been a fundamental theme of many studies (YE, 2000). This author concludes that effective measures must be taken to ensure sufficiently abundant spawning to prevent recruitment overfishing, and at the same time to recognise that the identification of the causal relationship between spawning stock and recruitment does not exclude possible effects of environmental variables on recruitment. F. paulensis presents great variability in recruitment, in which factors such as temperature, salinity, rainfall contribution and food availability (LEITE and PETRERE, 2006) and the influence of climate variability known as ENSO events, generate variations in the abundances of the species in its various habitats (MÖLLER et al., 2009; PEREIRA and D'INCAO, 2013). These variations are enhanced by the fishery of juveniles in coastal lagoons by small scale fisheries in Brazil and Uruguay (VALENTINI et al., 1991; FABIANO and SANTANA, 1999; D'INCAO, 2002; MÖLLER et al., 2009) and adults fisheries in the ocean by the Brazilian industrial fleet (VALENTINI et al., 1991; D'INCAO et al., 2002; LEITE and PETRERE, 2006).

The coastal lagoons of Uruguay are large bodies of great water productivity and serve as nurseries for many species of fish and invertebrates, juvenile F. paulensis being the main species of commercial interest (NORBIS, 2000; FABIANO and SANTANA, 2006).They are the southern part of the Brazilian system of coastal lagoons, presenting shallow waters and corresponding to temperate climate ecosystems. Temperatures can vary between 4 and $28{ }^{\circ} \mathrm{C}$ and salinity range is 1 to $24 \mathrm{ppt}$, the lagoons thus having polihaline characteristics. The connection to the sea is variable and salinity is the parameter that determines the aquatic biota that has an ample range of registers (SANTANA and FABIANO, 1999; FABIANO and SANTANA, 2006).

The fishery in Uruguay is controlled by the National Fisheries Agency (DINARA), which determines the number of fishing licenses, minimum permitted weight (set at $10 \mathrm{~g}$ ), closure areas inside the lagoons and type of gear to be used for the catch. Artisanal fishery is characterized by the use of unsophisticated technologies, small boats of limited autonomy, of less than 3 gross tons. Crews are of 1 or 2 hands, usually including the owner of the boat and relatives or members of the same community. Shrimp are caught in the coastal lagoons by means of small lights floating on the surface and fyke nets, 2 or more being placed by each light (FABIANO and SANTANA, 2006). About 200 people work in this fishery, it being of great economic importance for the country and for these people it is their largest source of income of the year. Thus the importance of determining and establishing fishery information and its variations associated with climate change.

The objective of this study was to undertake an analysis of catches of Farfantepenaeus paulensis in the coastal lagoons of Uruguay and their relationships with the 
Oceanic Niño Index (ONI), presenting and comparing the results of the growth of the species in the coastal lagoons of Uruguay with those obtained in Brazilian waters.

\section{MATERIAL AND METHODS}

\section{CATChes}

The data regarding catches observed for each lagoon that had pink shrimp fisheries between 1988 and 2013 (ROCHA and CASTILLOS) were obtained from a combination of information from the random sampling of landings and field interviews with fishermen and middlemen that frequented points of sale about once a week (SANTANA et al., 2012).

The total catch was estimated by the method proposed by SPARRE and VENEMA (1997) where:

Estimated catch $=\mathrm{EC}=$ mean $\mathrm{CPUE} *$ Effort

mean CPUE $=\Sigma$ Observed Capture $/ \Sigma$ Effort

The effort was estimated by direct approximately weekly counting of the fyke nets and lanterns in each lagoon by night during the fishing period (harvest) from February to June each year.

\section{CATCHES - ONI INDEX}

The ONI index gives the variation of the mean sea surface temperature (SST) in the Niño 3.4 region. This index is defined as the average SST variation during the three months of the El Niño 3.4 region and is regarded as the principal measurement for the monitoring, evaluation and foretelling of ENSO. It is accepted that it is a phase of an El Niño or La Niña phenomenon when monthly effects are equal to or exceed $+/-0.5^{\circ} \mathrm{C}$, while other atmospheric variables remain constant. These anomalies must also meet the condition of persisting for 3 consecutive months. The ONI series from 1988 to 2013 were obtained from the NOAA Climate Prediction Center (CPC) (http://www.cpc. ncep.noaa.gov/products/analysis_monitoring/ensostuff/ ensoyears.shtml

In the South-West Atlantic, ENSO phenomenon (cold phase situation), produce abnormally dry months between October and March (ROPELEWSKI and HALPERT, 1989; CIOTTI et al., 1995; SEELIGER et al., 1997). The negative anomalies of precipitation in the Paraná and Uruguay river basins also result in the reduction of the discharge of the Rio de la Plata and the increases in the flow of warm water to the oceanic coast (PISCIOTTANO et al., 1994, ORTEGA and MARTINEZ, 2007). These factors can determine a greater approximation of the warm coastal waters ensuring penetration stages of shrimp coastal lagoons in situations of open bar. (Esta última frase precisa ser re-escrita para ser compreensível!)

The relationship between the values of the Oceanic Niño Index (ONI) in the previous year and the estimated total catch of shrimp for a determined season was performed for the 1988 - 2013 period by a linear relationship (RICKER, 1973).

\section{StruCture AND Growth OF POpulation}

To determine the estimated parameters of growth, length data were obtained from commercial catches (harvest) of the period 2009 - 2013 and from direct evaluation of postlarvae carried out between November and March (preharvest) in each year, according to the methodology proposed by NION et al. (1974) and SANTANA and FABIANO (1999).

Individuals were sampled on a weekly basis measuring weight (W g) and rostrum length (Lcr mm: spine end to back of cephalothorax) for each sex. Sex was determined by the presence of a petasma or thelycum for males and females, respectively. Mean, median, mode, range and standard deviation of length structure were considered for Castillos Lagoon during 2009-2013 and for Rocha Lagoon only for 2013. To compare our data with that of literature we use the equation $\mathrm{Lt}=0.472328+2.402911 *$ Lcr where Lcr is the rostrum length and Lt the total length of the shrimp, according to SANTANA and FABIANO (1999).

To evaluate the null hypothesis that there are no significant differences in the average length between sexes for individuals caught per year, Student's t test (t) was applied. Previously the assumption of homogeneity of variances between samples was checked by Levene's test (SOKAL and ROHLF, 1987). When the assumption of homogeneity of variances was not met, a nonparametric Kolmogorov-Smirnov (KS) (SOKAL and ROHLF, 1987) was used. To establish whether there were no significant differences in the size distribution for the same sex between years, analysis of parametric variance (ANOVA) was used and in case of non compliance with the assumptions, the nonparametric analysis of variance Kruskal-Wallis (KW) test was applied. When significant differences were found, we used as evidence a posteriori a parametric Tukey test or the non parametric test of Mann-Whitney corrected by the criterion of Bonferroni, (SOKAL and ROHLF, 1987). In all cases $p=0.05$ level of statistical significance was used. 
The length frequencies data were analyzed by FISAT software (FAO/ICLARM Tools for assessing STOCKS, 2005), part of the analysis tools of LFSA and COMPLEAT ELEFAN (GAYANILO et al., 1994; SPARRE and VENEMA, 1997). Parameters of $L \infty$ and $K$ of Von Bertalanffy growth function (BERTALANFFY, 1938) were estimated according to the ELEFAN I and Shepherd methods (PAULY and DAVID, 1981; SHEPHERD, 1987).

\section{RESULTS}

\section{CATches And ONI}

Values of total shrimp estimated catch (EC) in the two coastal lagoons for the period 1988 - 2013 ranges between 0.7 and 162 tons (Fig. 2). Significant fluctuations in EC and very high values in some years $(1990,1997,2009$ and 2012) were found. These observations are consistent with periods La Niña or neutral previous. The opposite occurs during periods of El Niño where low catches were recorded in subsequent years $(1992,1998,2003$ and 2004).

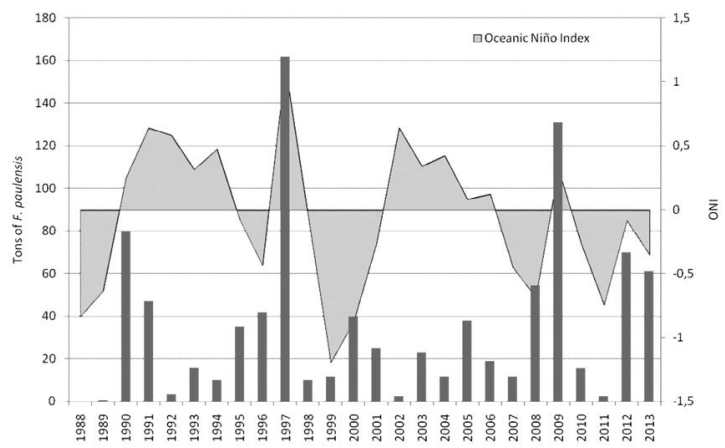

Figure 2. Harvest of pink shrimp in the Uruguayan coastal lagoons in relation to Oceanic Niño Index (ONI) for the period 1988 - 2013.

The relationship between ONI values and shrimp catches shows that the years with cold phases of ENSO, have high catches the following year (Fig. 2). While there is a negative trend in the ratio of the shrimp catch and positive values of ONI index (Fig. 3), the coefficient of determination is low $(\mathrm{R} 2=0.136)$ having an exception during 1997 (outlier value). This trend shows that highest catches appear during La Niña events (Fig. 4).

\section{STRUCTURE AND GROWTH OF POPULATION}

For each year significant differences between lengths of males and females were observed a females being always larger than males $(p<0.05$, Table 1). Also significant differences in the length achieved by males

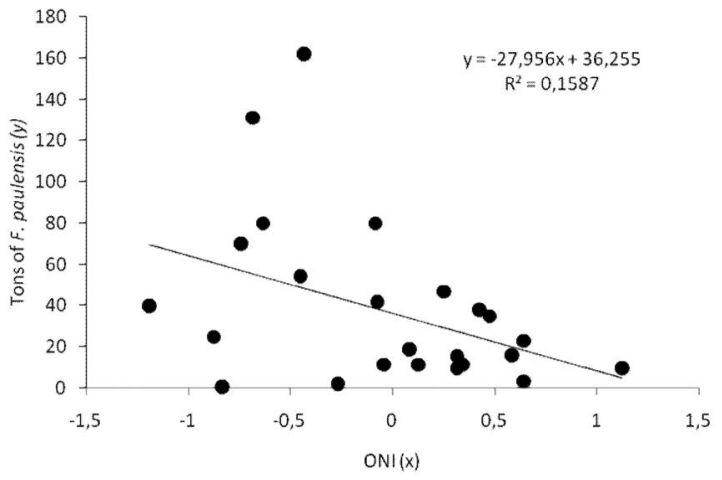

Figure 3. Estimated catch (EC) of pink shrimp in relation to ONI, showing a negative trend in positive periods of ONI and catch.

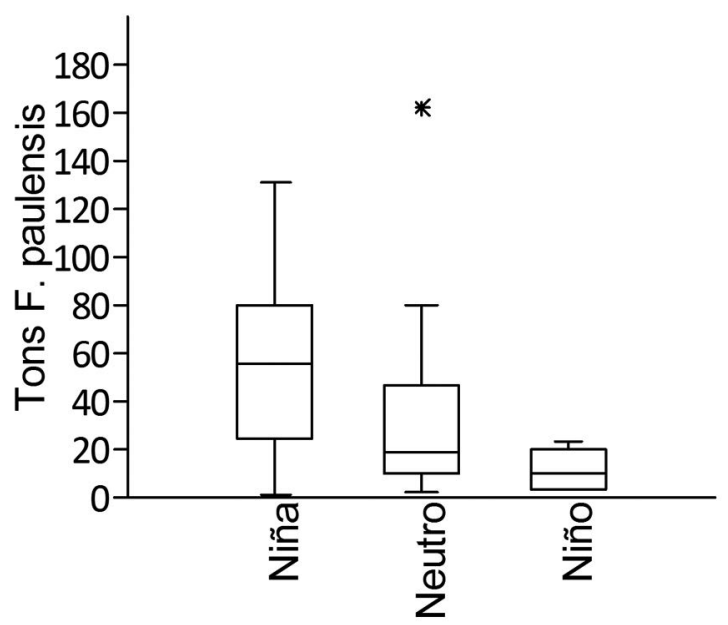

Figure 4. Box - plot of estimated catch (EC) (tons) of the pink shrimp season in Uruguayan coastal lagoons categorized by the occurrence of ENSO events.

and females were found between most years except in females for the years 2011-2012 and 2011-2013 ( $p$ $>0.05$ ). Finally, differences in the size of the shrimp between Rocha and Castillos, the former holding larger specimens.

The mean growth parameters were $\operatorname{Lcr} \infty=59,28 \mathrm{~mm}$ and $\mathrm{k}=1,48$ (Fig.5 and Table 2); ranging Lcr $\infty$ from 55 and $64,5 \mathrm{~mm} ; \mathrm{k}$ from 1,25 to 1,58 (Table 2). The lengths found in 2013 (Lcr 68,5 mm equal Lt $165 \mathrm{~mm}$ ) are the highest values reported up to date for Uruguay, belonging to Rocha lagoon (Table 3).

The parameters $\mathrm{K}$ were higher and $\mathrm{L} \infty$ were lower compared to those recorded for lagoons in Uruguay by SANTANA and FABIANO (1999) and NORBIS (2000). The adjustment values are adequate and the parameters are similar to those obseved in Brazil, being the L $\infty$ scarcely lower and the value of $\mathrm{K}$ quite similar (Tables 2 and 3). 
Table 1. Size structure (Lcr mm) of Farfantepenaeus paulensis in the coastal lagoons of Uruguay (2009-2013).

\begin{tabular}{|c|c|c|c|c|c|c|c|c|}
\hline Lagoon & Year & Sex & $\mathrm{n}$ & Mean & Median & Mode & Range & $\begin{array}{c}\text { Std } \\
\text { deviation }\end{array}$ \\
\hline \multirow[t]{10}{*}{$\begin{array}{l}\text { Castillos } \\
\text { Lagoon }\end{array}$} & 2009 & 우우 & 311 & 40.64 & 41.20 & 40.0 & $22.7-61.8$ & 5.71 \\
\hline & & $\hat{\sigma} \hat{\sigma}$ & 311 & 39.01 & 39.50 & 40.0 & $26.5-58.8$ & 4.06 \\
\hline & 2010 & 우우 & 226 & 34.88 & 34,95 & 34.0 & $23.3-44.2$ & 3.50 \\
\hline & & $\hat{\partial} \widehat{0}$ & 180 & 35.57 & 34.00 & 34.0 & $26.8-43.7$ & 2.76 \\
\hline & 2011 & 우우 & 142 & 41.08 & 37.85 & 34.0 & $20-62.4$ & 10.6 \\
\hline & & $\hat{\partial} \hat{\partial}$ & 146 & 37.20 & 35.15 & 26.5 & $19.5-52$ & 8.60 \\
\hline & 2012 & 우우 & 233 & 41.14 & 45.50 & 47.5 & $19.8-52.4$ & 9.03 \\
\hline & & $\hat{\partial} \hat{O}$ & 305 & 39.48 & 43.00 & 44.0 & $19.1-49.3$ & 7.40 \\
\hline & 2013 & 우우 & 232 & 30.40 & 29.60 & 28.2 & $20-48.6$ & 5.38 \\
\hline & & $\hat{\partial} \bar{\partial}$ & 203 & 29.80 & 29.60 & 28.5 & $19.8-43.9$ & 4.52 \\
\hline \multirow[t]{2}{*}{$\begin{array}{l}\text { Rocha La- } \\
\text { goon }\end{array}$} & 2013 & 우우 & 242 & 39.70 & 39.80 & 40.0 & $12.8-68.5$ & 5.31 \\
\hline & & $\widehat{\partial \widehat{\partial}}$ & 247 & 38.11 & 38.50 & 38.5 & $18.3-45.9$ & 3.80 \\
\hline
\end{tabular}

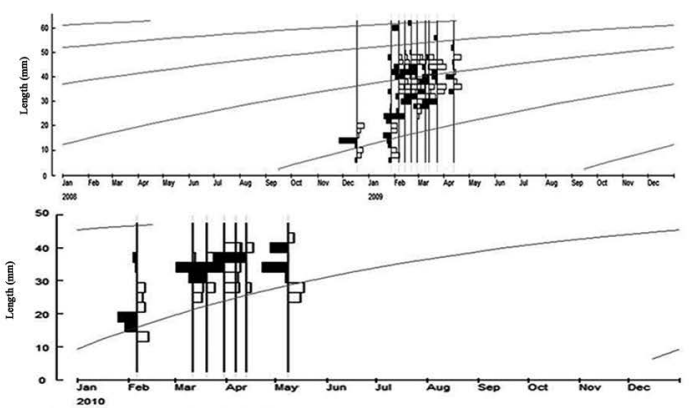

The growth curves for the Uruguayan coastal lagoons with a weekly period of length sampling (Fig. 5) seems to show on the projection on $\mathrm{x}$ axis, the start of incomes of the post-larvae's to the lagoons.

\section{DISCUSSION}

The catches and indeed the fraction of the population that reaches Uruguayan waters and enters the lagoons have high interannual variability. Catches also have a tendency to be higher later of cold phase (La Niña) ENSO phenomenon. The connection between the effects of ENSO phenomenon and its influence on regional local rainfall, produces abnormally dry months between October and March (period income of post-larvaes), when there is a situation of cold phase of the ENSO (ROPELEWSKI and HALPERT, 1989; PISCIOTTANO et al., 1994; CAZESBOEZIO et al., 2003). The clear exception to this rule is the year 1997, having as very high origin the mechanical aperture of all sand bars during late 1996 (outlier value in Fig. 4).

Decreased rainfall on the Rio de la Plata river basin,

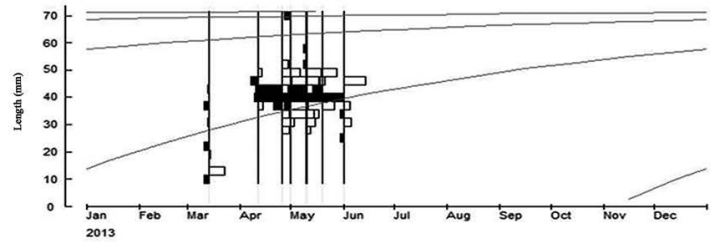

Figure 5. Restructured length frequency distributions estimated by ELEFAN-I for Farfantepenaeus paulensis for the artisanal fisheries data. generate a smaller runnoff favouring the southward flow of the Brazil Current (Tropical Water and South Atlantic Central Water) and Subtropical Shelf Water on the Uruguayan shelf (SVERDRUP et al., 1942; EMILSSON 1961; THOMSEN 1962; ORTEGA and MARTÍNEZ, 2007; MARTÍNEZ and ORTEGA, 2007). These conditions favour the presence of post-larvae in Uruguayan 
Table 2. Growth parameters for Farfantepenaeus paulensis in the coastal lagoons of Uruguay (2009-2013) estimated by ELEFAN and Shepherd. Error estimators for Shepherd score and ELEFAN Rn from FISAT II. (C: Castillos lagoon; R: Rocha lagoon).

\begin{tabular}{lcccccc}
\hline \multirow{\gamma}{*}{+} & $2009 \mathrm{C}$ & $2010 \mathrm{C}$ & $2011 \mathrm{C}$ & $2012 \mathrm{C}$ & $2013 \mathrm{C}$ & $2013 \mathrm{R}$ \\
\hline Lcr $\infty(\mathrm{mm})$ & 63.0 & 55.0 & 64.5 & 57.75 & 55.9 & 72.0 \\
$\mathrm{~K}$ & 1.51 & 1.55 & 1.58 & 1.25 & 1.4 & 1.4 \\
Shepherd score & 0.836 & 1 & 0.911 & 0.916 & 1 & 0.949 \\
ELEFAN Rn & 0.214 & 0.492 & 0.312 & 0.335 & 0.213 & 0.434 \\
\hline
\end{tabular}

Table 3. Compared growth parameters by different authors in the region (Melo, 1973; D'Incao, 1984; Norbis, 2000; Leite and Petrere, 2006 and present work).

\begin{tabular}{|c|c|c|c|c|c|c|}
\hline \multirow{2}{*}{ Authors } & \multicolumn{3}{|c|}{ Ltot $\infty(\mathrm{mm})$} & \multicolumn{3}{|c|}{$\mathrm{K}$} \\
\hline & 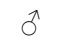 & q & jo우 & $\widehat{0}$ & q & o우 \\
\hline Mello (1973) & 165 & 205 & - & 1,25 & 2,4 & - \\
\hline D'Incao (1984) & 193 & 248 & - & 1,25 & 1,03 & - \\
\hline Santana and Fabiano (1999) & - & - & 163 & - & - & 0,38 \\
\hline Norbis $(2000)$ & - & - & 165 & - & - & 0,52 \\
\hline Leite and Petrere (2006) & 210 & 250 & 275 & 0,8 & 1,1 & 1,34 \\
\hline Present work & - & - & 177 & - & - & 1,4 \\
\hline
\end{tabular}

waters entering the coastal lagoons and its growth there (SANTANA and FABIANO 1992). This agree with MÖLLER et al. (2009) who reported that the income of post-larvae in Patos Lagoon (Southern Brazil) would be associated with the decrease of precipitations in the upper basins. Projection of growth curve to the intercept with the $\mathrm{x}$ axis (to) assumes an income of post-larvae to the coastal ecosystems from November to December. This matches the months of peak of abundance (obs. pers.), the openness of the sand bars during spring summer, and northeast winds and tidal maximum associated with new and full moons of that period (GARCÍA and LE RESTE, 1986; NORBIS, 2000).

The shrimp seasons occur during autumn and showed similar growth parameters as in neighbouring lagoons of southern Brazil. The $\mathrm{k}$ value greater than the calculated by LEITE and PETRERE (2006) and this may be explained by higher productivity of the Uruguayan lagoons. Our data, and the maximum length found in Uruguay, indicate that in most years $F$. paulensis enters to coastal lagoons of Uruguay in the spring as post-larvae, reaches in these ecosystems total lengths between $100 \mathrm{~mm}$ and $165 \mathrm{~mm}$ in a period of about 5- 7 months, and then begin their return to the sea. Regarding size differences in the size of the shrimp between Rocha and Castillos, our results agree with previous data (FAO, 1965; NION et al., 1974; SANTANA and FABIANO 1999), i. e. specimens in Rocha reaches larger sizes than in Castillos. Causes for these differences remain to be assessed.
Estimated growth parameters show similar values through different years and using different estimation methods. These estimation parameters are limited by the fact that this coastal fishery acts in just a part of the entire life cycle. Nevertheless, we can assume that there would be a spawning stock near the Uruguayan lagoons as does GUSMÃO et al. (2005). Given the coincidence of estimated growth parameters calculated for the lagoons with those obtained in marine populations (MELLO, 1973) for the State of São Paulo, it is possible to assume that individuals who migrate from coastal lagoons in autumn join the spawning stock of southern coast of Brazil. However these results should be complemented with genetic studies to $F$. paulensis in Uruguayan and Brazil waters.

The differences in the values of $\mathrm{K}$ observed in this study in relation to NORBIS (2000) and SANTANA and FABIANO (1999) can be given by environmental variations and changes in the conditions of the lagoons (aperture of sand bars, temperature, salinity, rainfall) which affect the growth of shrimp in these ecosystems (ALBERTONI, 2003).

Due to the fact that the population of pink shrimp is common to both countries (Brazil and Uruguay), a cooperative management of this species is needed, considering that it sustains the economic activity of hundreds of artisanal fishermen. Further research is needed for a better comprehension of the complex life cycle of this Atlantic penaeoid shrimp. 


\section{ACKNOWLEDGEMENTS}

The authors wish to thank Fabrizio Scarabino, Martin Laporta and the anonymous reviewers for their critical comments on this study. We are also grateful to the artisanal fishermen of the coastal lagoons of Uruguay who were unsparing in their support of the different stages of our fieldwork.

\section{REFERENCES}

ALBERTONI, E. F.; PALMA-SILVA, C.; ESTEVES, F. A. Crescimento e fator de condição na fase juvenil de Farfantepenaeus brasiliensis (Latreille) e F. paulensis (Pérez-Farfante) (Crustacea, Decapoda, Penaeidae) em uma lagoa costeira tropical do Rio de Janeiro, Brasil. Rev. Bras. Zool., v. 20, n. 3, p. 409-418, 2003.

BERTALANFFY, L. V. A quantitative theory of organic growth. Hum. Biol., v. 10, p. 181-243, 1938.

CIOTTI, A. M.; ODEBRECHT, C.; FILLMAN, G. Y.; MÖLLER Jr. O. O. Freshwater outflow and subtropical convergence influence on phytoplankton biomass on the southern Brazilian continental shelf. Cont. Shelf Res., v.15, n. 14, p.1737-56, 1995.

CAZES-BOEZIO, G.; ROBERTSON, A. W.; MECHOSO C. R. Seasonal dependence of ENSO teleconnections over South America and relationships with precipitation in Uruguay. J. Climate, v. 16, n. 8, p. 1159-1033, 2003.

D'INCAO, F. Estudo sobre o crescimento de Penaeus (Farfantepeneus) paulensis Pérez Farfante, 1967 da Lagoa dos Patos, RS, Brasil, Decapoda, Penaeidae. Atlântica, Rio Grande, v. 7, p. 73-84, 1984.

D'INCAO, F. Pesca e biologia de Penaeus paulensis na Lagoa dos Patos, RS, Brasil. Atlântica, Rio Grande, v.13, n. 1, p. 159-169, 1991.

D'INCAO, F. Subordem Dendrobranchiata (camarões marinhos). In: Buckup, L.; BondBuckup, G. (Eds.). Os camarões do Rio Grande do Sul. Porto Alegre: Editora da Universidade UFRGS, 1999. p. 271-299.

D'INCAO, F.; VALENTINI, H.; RODRIGUES, L. F. Avaliação da pesca de camarões nas regiões Sudeste e Sul do Brasil. 1965-1999. Atlântica, Rio Grande, v. 24, n. 2, p. 49-62, 2002.

EMILSSON, I. The shelf and coastal waters off southern Brazil. Bol. Inst. Oceanogr., v.11, n. 2, p. 101-112, 1961.

FABIANO, G.; SANTANA, O. Las pesquerías en las lagunas costeras salobres de Uruguay. In: MENAFRA, R.; RODRÍGUEZ-GALLEGO, L.; SCARABINO, F.; CONDE, D. (Eds.). Bases para la conservación y manejo de la costa uruguaya. Montevideo: Vida Silvestre, 2006. p. 557-565.

FAO/UN. Informe a los gobiernos de Brasil, Uruguay y Argentina sobre investigación y determinación de los recursos camaroneros Basado en el trabajo de Michael N. Mistakidis. Roma: Rep. FAO/EPTA, 1965. 48 p.

GARCÍA, S.; LE RESTE, L. Ciclos vitales, dinámica, explotación y ordenación de las poblaciones de camarones peneidos costeros. Roma: FAO Doc. Téc. Pesca., v. 203, p.180, 1986.

GAYANILO, F.C., J. R.; SPARRE, P.; PAULY, D. The FAOICLARM Stock Assessment Tools (FISAT) User's Guide. Roma: FAO Computerized Information Series (Fisheries), 1994. 124 p.
GUSMÃO, J.; LAZOSKI C.; SOLÉCAVA, A. Population genetic structure of Brazilian shrimp species (Farfantepenaeus sp., F. brasiliensis, F. paulensis and Litopenaeus schmitti: Decapoda: Penaeidae). Genet. Mol. Biol., v. 28, n. 1, p.165-171, 2005.

LEITE JÚNIOR, N. O.; PETRERE JÚNIOR, M. Stock assessment and fishery management of the pink shrimp Farfantepenaeus brasiliensis Latreille, 1970 and F. paulensis Pérez Farfante, 1967 in Southeastern Brazil $\left(23^{\circ}\right.$ to $\left.28^{\circ} \mathrm{S}\right)$. Braz. J. Biol., v. 66, n. 1B, p. 263-277, 2006.

MARTÍNEZ, A., ORTEGA, L. Seasonal trends in phytoplankton biomass over the Uruguayan Shelf. Cont. Shelf Res., vol. 27, n 12, p. 1747-1758, 2007.

MELLO, J. T. C. Estudo populacional do camarão "rosa" $P e$ naeus brasiliensis (Latreille, 1817) e Penaeus paulensis (Perez FarfantE, 1967). Bol. Ins. Pesca., v. 2, n. 2, p. 1-65, 1973.

MÖLLER, O. O.; CASTELLO, J. P.; VAZ, A. C. The effect of river discharge and winds on the interannual variability of the pink shrimp (Farfantepenaeus paulensis) production in Patos Lagoon. Estuar. Coast., v. 32, n. 4, p. 78-796, 2009.

NION, H.; VARELA, Z.; CASTALDO, H. Evaluación de los recursos pesqueros en el Sistema Laguna de Castillos, Arroyo de Valizas, año 1974. Roma: FAO, CARPAS, 1974. 38 p.

NORBIS, W. Estudios sobre la población de camarón rosado (Penaeus paulensis) en las lagunas costeras de la Reserva de Biosfera Bañados del Este/Rocha: PROBIDES, (Documentos de Trabajo; 28), 2000. 40 p.

ORTEGA, L.; MARTINEZ, A. Multiannual and Seasonal Variability of Water Masses and Fronts over the Uruguayan Shelf. J. Coast. Res., v. 23 n. 3, p. 618-629, 2007.

PAULY, D.; DAVID, N. ELEFAN I. A Basic program for the objective extraction of growth parameters from length frequency data. Meeresforsch, v. 28, p. 205-211, 1981.

PEREIRA, N.; D‘INCAO, F. Relationship between rainfall, pink shrimp harvest (Farfantepenaeus paulensis) and adult stock, associated with El Niño and La Niña phenomena in Patos Lagoon, southern Brazil. J. Mar. Biol. Ass. U. K., v. 92, n. 7, p. 1451-1456, 2013.

PISCIOTTANO, G.; DÍAZ, A.; CAZES, G.; MECHOSO, C.R. El Niño Southern oscillation impact on rainfall in Uruguay. J. Climate, v. 7, n. 8, p. 1286-1304, 1994.

RICKER, W. E. Linear regression in fisheries research. J. Fish. Res. Board Can., v. 30, p. 409-434, 1973.

ROPELEWSKY, C. F.; HALPERT, M. S. Precipitation patterns associated with the high index phase of the Southern Oscillation. J. Climate, v. 2, p. 268-284, 1989.

SANTANA, O.; FABIANO, G. Aspectos relevantes del camarón rosado (Penaeus paulensis) en las lagunas costeras uruguayas. Frente Marítimo, v. 12, p. 89-94, 1992.

SANTANA, O.; FABIANO, G. Medidas y mecanismos de administración de los recursos pesqueros de las lagunas costeras del litoral atlántico del Uruguay (Lagunas de José Ignacio, Garzón, Rocha y Castillos). Montevideo: Instituto Nacional de Pesca, 1999. 165 p.

SANTANA, O; G FABIANO; SILVEIRA, S. El camarón rosado: un favorito de la gastronomía regional. Infopesca Int., v. 50, p 29-33, 2012.

SEELIGER, U; ODEBRECHT, C.; CASTELlO, J. P. (Eds.). Subtropical convergence environments: the coast and sea in the southwestern Atlantic. New York: Springer, 1998. 308 p. 
SHEPHERD, J. G. A weakly parametric method for estimating growth parameters from length composition data. In: PAULY, D.; MORGAN, G. R. (Eds.). Length based methods in fisheries research. ICLARM Conference Proceedings, Manila, 1987. p. 113-119.

SOKAL, R.; ROHLF, F. Introduction to biostatistics. 2nd ed. New York: Freeman, 1987.

SPARRE, P.; VENEMA, S.C. Introducción a la evaluación de recursos pesqueros tropicales. Doc. Tec. Pesca - Parte 1. Manual. Roma: FAO, 1997. 420 p

SVERDRUP, H. U.; JOHNSON, M.; FLEMING R. The Oceans. Their physics, chemistry and general biology. New York: Prentice Hall, 1942. 1087 p.

THOMSEN, H. Masas de agua características del Océano Atlántico (parte Sudoeste). Buenos Aires: Servicio de Hidrografía Naval, Secretaría Marina, Publ H632, 1962. p. 1-27.
VALENTINI, H.; D‘INCAO, F.; RODRÍGUES, F. L.; Rebelo Neto, J. E.; RAHN, E. Análise da pesca do camarão rosa, Penaeus brasiliensis e Penaeus paulensis, nas regiões Sudeste e Sul do Brasil. Atlântica, Rio Grande, v.13, n. 1, p. 143-157, 1991.

VILLEGAS, F. Informe preliminar sobre las posibilidades de cultivo de langostino Penaeus paulensis en lagunas salobres de Uruguay. Roma: FAO Inf. Pesca, v. 159, n. 1, p. 374, 1974.

YE, Y. Is recruitment related to spawning stock in penaeid shrimp fisheries? ICES J. Mar. Sci., v. 57, n. 4, p. $1103-$ 1109, 2000.

ZENKER, H. H.; AGNES, J. L. Distribuição do camarão rosa Penaeus brasiliensis e Penaeus paulensis ao longo da costa sudeste e sul do Brasil. Sér. Doc. Tec., v. 21, p. 1-105, 1977. 